\title{
METHODOLOGY OF SEISMIC BLASTING IN QUARRIES
}

\author{
B. Pandula ${ }^{1}$, J. Kondela ${ }^{1}$, I. Buchla 2 , J. Baulovič ${ }^{3}$ \\ ${ }^{1}$ Institute of Geosciences, BERG Faculty, Technical University of Košice, Slovakia - blazej.pandula, julian.kondela @ tuke.sk \\ ${ }^{2}$ Carmeuse Slovakia s.r.o., Košice, Slovakia - ibuchla@ carmeuse.sk \\ ${ }^{3}$ B blast s.r.o., Jasenov, Slovakia - jbaulovic@ centrum.sk
}

\author{
Commission V, WG V/7
}

KEY WORDS: Blasting in quarries, Seismic waves, Millisecond timing delay, Peak particle velocity, Seismic waves attenuation law, Seismic safety.

\begin{abstract}
Blasting induced vibration is one of the fundamental problems in the quarries and intense vibration can cause critical damage to environment nearby the quarries. Blasting operations generate seismic waves with different maximum particle velocity and wide spectrum of frequencies. This process depends on the properties of the rocks, properties of charges and technology of blasting. It is very important to study how to control vibration induced by blasting in the mitigation of negative effects of blasting in quarries. Maximum values of the particle velocity are depended on great number of different factors. The article presents the results of the analysis as well as an evaluation methodology of seismic safety of the objects during blasting work held by the seismic waves' attenuation law and milisecond timing. Methodology of the evaluation of seismic effects of blasting are base for evaluation of the effects of seismic blasting in quarries in Slovakia.
\end{abstract}

\section{INTRODUCTION}

Mining of raw materials is currently in larger, but also smaller surface mining operations is carried out by means of blasting works. Blasting works are technically and economically the most acceptable tool for breaking up hard rocks and affects the entire mining operation. It has an impact on the method and speed of loading, transporting, crushing and finalizing the product. Proper fragmentation has an impact on the maintenance and repair of operating equipment in quarries. Despite its positive contribution, human society perceives it negatively. The reasons are related to its side effects noise, dust and technical seismicity (Fig.1). From the point of view of safety, the stability of buildings, infrastructure and the preservation of natural phenomena (water resources, caves) is dominated by concerns mainly about the negative seismic effects of blasting.

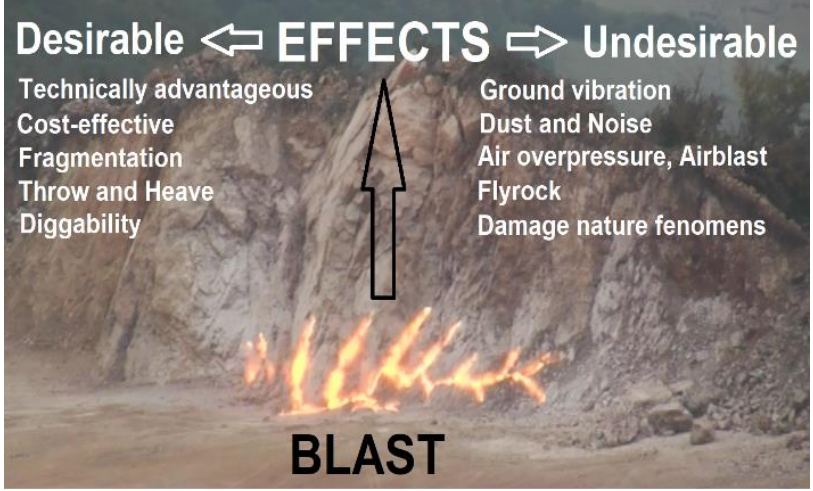

Figure 1. Desirable and undesirable effects of a blasting operation.

Seismic of blasting is a part of engineering seismic. In practice, the seismics of blasting work focuses mainly on solving the following problems:
- measuring and evaluating the effects of a known source of shocks on a defined receptor,

- prognosis of the effects of a known source on possible nearby receptors and the environment.

Virtually all blasting seismics are created by a combination of three basic input parameters and their mutual interaction (Pandula and Kondela, 2010).

\section{1. source of vibration, \\ 2. transmission environment, \\ 3. receptor.}

The presented results are mainly based on experimental and applied research carried out in active, largest surface mining operations in the last 20 years in Slovakia with permanent mining (Včeláre, Vajarská, Gombasek, Trebejov, Maglovec, Malá Vieska, Lietavská Lúčka, Mníchová Lehota, Trenčianské Mitice, Kučín, Nižný Hrabovec, and others). Using seismic apparatus, we investigated the seismic effects of blasting work in a real rock environment in the near source zone. We recorded, interpreted and evaluated individual types of seismic waves arising during blasting in various rock environments (limestone, dolomites, sandstones, zeolites, andesites, diorite porphyrites). We determined the particle velocity, propagation and frequency of seismic waves generated by blasting work at different parameters of individual blasts. The evaluation of the seismic effects of blastings at different parameters in different rock environments showed a significant effect of millisecond timing on the attenuation of seismic waves. Likewise, the degree of disturbance of the rock environment in which the waves propagated was important in attenuation the effects of seismic loading on the receptors. We used the obtained data and methods for measuring and evaluating the effects of technical seismicity to optimize blasting works so, that the negative seismic effects on different types of receptors are as low as possible. 


\section{SOURCE OF VIBRATION}

The source of vibrations during blasting work in quarries is the explosion of an explosive charge. An explosion is a rapid physical or physico-chemical event that results in a rapid release of internal energy into mechanical energy, which can result in high pressure or temperature of the explosive gases (Henrych, 1973). The magnitude of the vibration depends on the total weight of the explosive (charge) that explodes at the time of firing. The aim of the blasting work is to disengage the largest possible rock tonnage. The more we increase the total charge, the more rock we get, but the magnitude of vibrations and other negative effects increases.

To reduce the amount of vibrations generated by blasting, it is necessary to divide the total weight of the charge into smaller charges. It is necessary that the effect of individual smaller charges during the blasting cooperate to disengage the rock mass. The optimal interference of individual smaller charges depends on the time delay of their firing.

Distribution of blasting according to the timing delay of firing of individual charges (STN EN 1998-1/NA/Z1):

- instantaneous (all charges explode at the same time),

- timed (partial charges explode at different graduated time intervals

Multiple blast charges can be exploded at the same time, which we consider to be one partial blast charge.

In timed blasting, we consider two time intervals $\Delta t$ :

- $\Delta t \geq 250 \mathrm{~ms}$ (vibrations attenuate before the next sub-charge explodes),

- $\quad \Delta t<250 \mathbf{~ m s}$ (partials firings charge load attenuate vibrations effects).

The required length of the timing limit depends on the rock environment and can drop from $250 \mathrm{~ms}$ to $\Delta t=10 \mathrm{~ms}$.

Based on both experimental and applied research (Tatsuya et al 2000; Kondela, Pandula, 2012; Baulovič et al. 2016; Pandula, Kondela, 2021), it has been shown that the timing limit interval length can drop to less than $10 \mathrm{~ms}$, but must be greater than $5 \mathrm{~ms}$. An instantaneous explosion occurs if the timing interval length is less than $5 \mathrm{~ms}$.

In the graph of Fig. 2 is shows, that the maximum compressive stress when firing one borehole lasts $2.5 \mathrm{~ms}$. Therefore, it is necessary that the time firing delay of individual boreholes is more than $2.5 \mathrm{~ms}$.

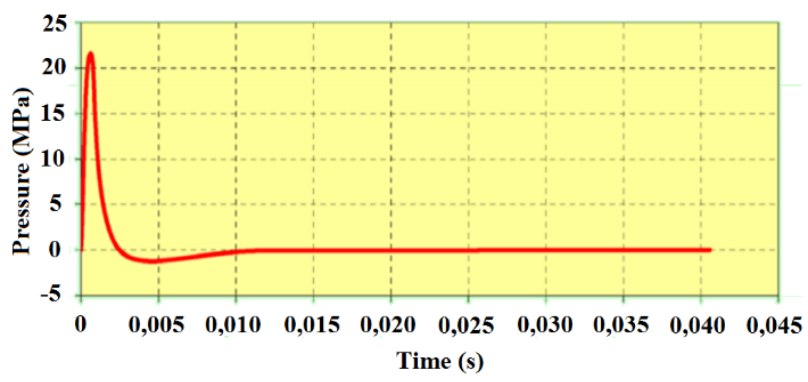

Figure 2. Graph of the pressure wave course during an explosion (Makovička, Makovička, 2004).

Knowledge of the explosion processes is important for the correct assessment of the seismic effects of blasting. An explosion is a rapid physical or physico-chemical event that results in a rapid release of internal energy into mechanical energy, which can result in high pressure or temperature of the explosive gases. (Henrych, 1973)

A very important parameter for optimizing the seismic effects of blasting works is the millisecond timing delay firing of individual boreholes during blasting. In the graph of Fig. 2 shows, that the maximum compressive stress of blasting one borehole lasts 2.5 $\mathrm{ms}$. Therefore, the timing delay of individual boreholes needs to be more than $2.5 \mathrm{~ms}$. During blasting work, it is assumed that the method of determining the time of delay of firing of individual boreholes is determined according to the structural properties of the rock environment. During the millisecond timing of blasting work, waves from several sources propagate at the same time firings of individual boreholes. With the same period but with a different phase, each point of the environment oscillates. The resulting oscillation is the sum of the vectors of the given partial oscillations. The simplest case of interference is the interference of two waves of the same wavelength, traveling through the environment at the same phase speed and in the same direction. Such a case of interference is during blasting work. The resulting amplitude at the interference of two identical waves is the largest at the collision sites of the same phase, the smallest at the collision sites of the opposite phase. Two seismic waves can achieve the maximum attenuation of vibration when the timing delay is the half-period of waves propagation. In the literature (Langefors and Kihlström, 1978; Dojčár et al. 1996; Tatsuya et al. 2000; Pandula and Kondela, 2010) the timing delay is reported according to the experience of many projects. Langefors proposed the interval of millisecond timing delay as follows $\Delta \mathrm{t}=\mathrm{T} / 2$ ( $\mathrm{T}$ is the period of vibration waves). This causes the vibrations to dampen each other under conditions of a constant vibration cycle and the same types of vibrations. Therefore, it is necessary to design a millisecond timing of blasting work depending on the structural properties of the rock environment. The properties of the rock mass in which the blasting works are performed are obtained by measuring the oscillation velocities and the frequency of propagation of seismic waves in situ. The frequencies of the measured seismic waves are determined on the basis of spectral analysis (Viskup et al. 2005; Kondela, Pandula, 2012).

FFT analysis of the experimental measurements of seismic wave propagation at the profiles in the quarry Trebejov identified (Fig. 3 ), that the frequencies at the individual profiles are different. Frequencies $\mathrm{f} \leq 30 \mathrm{~Hz}$ dominated. The measured frequencies are the result of the passage of seismic waves through a specific disrupted dolomite rock massif.

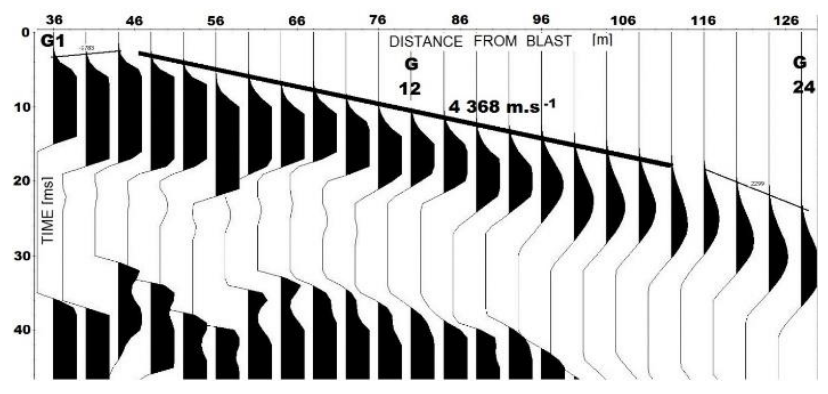

Figure 3. Seismic record accomplished with measuring apparatus Terraloc Mk 8 of the seismic profile with identified propagation velocity of seismic wave $4368 \mathrm{~m} \cdot \mathrm{s}^{-1}$, frequency 24

$\mathrm{Hz}$ from blasting in the rock massif of the dolomites in the quarry Trebejov (G1 to G24 - number of geophones on the measuring profile).

According to the theory on seismic waves propagation and attenuation the biggest attenuation can be achieved at millisecond 
timing only if the waves generated by further blast are in the opposite phase. Due to the calculations made by Leššo, at the frequency $30 \mathrm{~Hz}$ of the seismic waves it can be achieved applying the millisecond timing $17 \mathrm{~ms}(\Delta \mathrm{t}=\mathrm{T} / 2=1 / 2 \mathrm{f}=1 / 60=0.017 \mathrm{~s})$ In case of seismic waves propagation $4300 \mathrm{~m} \cdot \mathrm{s}^{-1}$ maximum attenuation can be achieved in distance $70 \mathrm{~m}$ from the blast. (Leššo, 2018)

\begin{tabular}{|c|l|l|l|}
\hline \multirow{2}{*}{$\begin{array}{c}\text { Velocity of } \\
\text { seismic } \\
\text { waves } \\
\text { propagation } \\
4300 \mathrm{~m} . \mathrm{s}^{-1}\end{array}$} & $\begin{array}{l}\text { Frequencies } \\
(\mathrm{Hz})\end{array}$ & $\begin{array}{l}\text { Timing } \\
\text { delay } \\
(\mathrm{ms})\end{array}$ & $\begin{array}{l}\text { Distance } \\
\text { from } \\
\text { blasting }(\mathrm{m})\end{array}$ \\
\cline { 2 - 4 } & 24 & 17 & 70 \\
\cline { 2 - 4 } & 20 & 20 & 86 \\
\hline
\end{tabular}

Table 1. Maximum vibration attenuation depending on the propagation velocity of seismic waves and their frequency and distance from blasting.

\section{TRANSMISSION ENVIRONMENT}

Detonation of an explosive charge, whether the environment is gaseous, liquid or solid, always has a very strong impact on the environment. During industrial blasting, we are particularly interested in the phenomena that take place in the rock massif. At the same time, however, we must also be interested in the environment between the rock mass and the receptor, the socalled transmission environment. (Henrych, 1973)

The transmission environment is air, water, soil, rock, part of the structure, etc. In the case of blasting work, it is mainly the transmission of seismic waves through the rock environment. Currently, the development of knowledge about the rock environment is based on the geological and geotechnical research. One of them is the knowledge of the real state of failure of the rock massif. The natural rock mass is permeated by a system of cracks, fissures and fractures, which affect the process of dismantling the rock mass with the energy of the explosion as well as the process of propagation of seismic waves in the transmitted environment. (Henrych, 1973)

Blasting works disturb the equilibrium state in the rock massif. There is a violent release of accumulated energy and the emergence of a new stress system, which causes the deformation of the rock mass. According to Mosinec (1976), the history of rocks, their mineralogical composition, the alternation of secondary processes such as serpentinization. dolomitization and crystallization, porosity increase / decrease, humidity and pressure - all these parameters are reflected in the speed of propagation of elastic waves, and therefore make speed a measure of data on rock properties. The propagation speed of seismic waves depends on the propagation rate in the solid part (skeleton) of the rock, on the porosity (percentage of pore volume / rock volume), on the propagation speed with filled pores and on the firing parameters. In general, the seismic velocity in high-pore rocks is lower compared to low-pore rocks. Also, the velocity is significantly higher in an environment saturated with water than in unsaturated rocks with the same pore content. The rate of rock propagation is influenced by its mineralogy, as the nature of the pore filling (air, water) is usually lower than the rate of rock propagation (Pandula and Kondela, 2010).
Based on research conducted in the quarry Včeláre it was found, that even in the case of measuring the same blast at the same measurement stanpoint by several of the same instruments, it is possible to obtein variance of the measured vibration characteristics. Therefore, we are set a mathematical-statistical approach to measuring, evaluating and assessing the seismic effects of blasting. Theory and experiments in many quarries have shown that the peak particle velocity is well governed by the semi-empirical law of seismic wave attenuation, which is given by the relationship

$\mathbf{v}=\mathbf{K}\left(\frac{\mathbf{L}}{\mathbf{Q}^{\mathbf{0 , 5}}}\right)^{-\mathbf{n}}=\mathbf{K}\left(\frac{\mathbf{Q}^{0,5}}{\mathbf{L}}\right)^{\mathbf{n}}\left[\mathrm{mm} . \mathrm{s}^{-1}\right]$,

where $\mathrm{K}, \mathrm{n}$ are determined by experimental measurements,

$$
\begin{aligned}
& \mathrm{Q}=\text { charge charge weight }[\mathrm{kg}], \\
& \mathrm{L}=\text { distance }[\mathrm{m}] \text { (Dojčar, Pandula,1996). }
\end{aligned}
$$

There is a theoretical relationship between effect and cause between the two variables, the value of the peak particle velocity PPV and the reduced distance $L_{R}$. Due to the large dispersion of the registered values PPV from one blast to another, from one measurement standpoint to another, the peak particle velocity PPV is considered as a dependent variable and the reduced distance

$$
\mathbf{L}_{\mathbf{R}}=\left(\frac{\mathbf{L}}{\mathbf{Q}^{\mathbf{0 , 5}}}\right) \text { as an independent variable. Both quantities are }
$$

bound not functionally but stochastic. Thus, on the basis of test blasts, it is possible to determine the law of attenuation of seismic waves for the researched area by the methods of mathematical statistics. Relationship (1) logarithmization

$$
\log \mathbf{v}=\log K-\mathbf{n} \cdot \log \left(\frac{\mathbf{L}}{\mathbf{Q}^{0,5}}\right)
$$

we have a relation, which in rectangular logarithmic coordinates represents a line with an angle $\beta$. The parameters $n$ and $K$ of this regression line are determined statistically (Sambuelli, 2009).

In order to accurately determine the law of attenuation of seismic waves between the source of blast and the receptor, it is necessary to measure the values of the peak particle velocity PPV near the source of blast and at the receptor. During practical measurements of blasting in quarries, the smallest distance of the sensor from the source blastings was determined to be $25 \mathrm{~m}$ (Fig.4). At shorter distances, the sensor shifts and possible measurement inaccuracy.

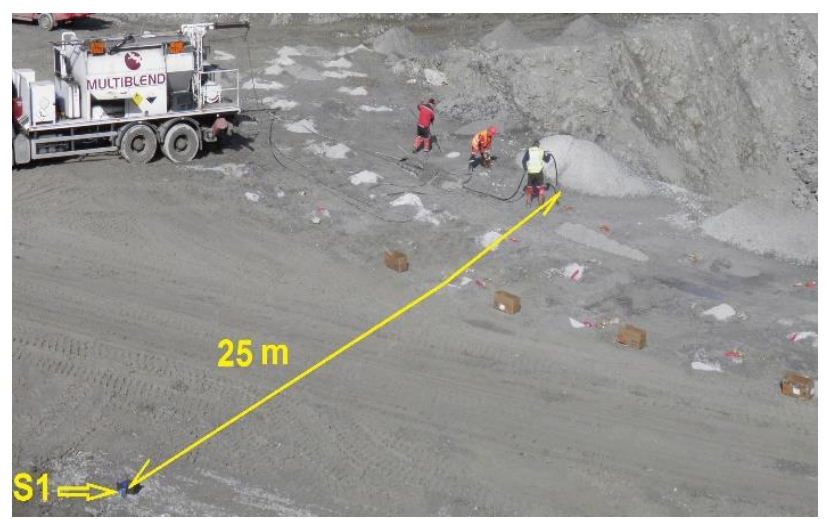


Figure 4. Position of the Vibraloc ABEM seismic apparatus on the measuring profile, measurement standpoint $\mathrm{S} 1$ at a distance of $25 \mathrm{~m}$ from the mouth of the borehole, when measuring the peak particle velocity PPV during blasting in the quarry

(Pandula, Kondela, 2021).

On the receptors the peak particle velocity sensors must be placed on the reference measurement standpoint, which is defined by technical norm (Pandula and Kondela, 2021).

\section{APPLICATION OF THE METHOD IN PRACTICE}

Based on the measured data during the operational blasting in the quarry, a graphical dependence of the maximum components of the peak particle velocity on the reduced distance in bench blasting was constructed. The graph in Fig. 5 represents the so-called seismic wave attenuation law for the quarry, in which the value of $\mathrm{Q}$ in the form

$$
v=\left(\frac{L}{Q^{0,5}}\right)=K\left[\frac{L}{Q^{0,5}}\right]^{n},
$$

where $\mathrm{v}=$ the peak particle velocity (maximum component of the vibration velocity) generated by the blast, $\left[\mathrm{mm} \cdot \mathrm{s}^{-1}\right]$,

L. $\mathrm{Q}^{-0.5}=$ called reduced distance, $\left[\mathrm{m} . \mathrm{kg}^{-0.5}\right]$,

$\mathrm{L}=$ the shortest distance of the blast from receptor, $[\mathrm{m}], \mathrm{Q}=$ the charge weight per borehole, $[\mathrm{kg}]$,

$\mathrm{K}=$ the factor depends on the blast conditions, the properties of the transmission environment, the type of explosive, etc.,

$\mathrm{n}=$ an indicator of seismic wave attenuation (Dojčár et al. 1996; Pandula and Kondela, 2010; Pandula et al. 2012).

From the law of attenuation of seismic waves, it is possible to determine the size of the charge weight for a specific receptor at a known distance, so that the maximum values of individual components of the oscillation velocity do not exceed the permitted peak particle velocities. The graphical course of the law of attenuation of seismic waves for the quarry shows, that the permissible peak particle velocity of $3 \mathrm{~mm} . \mathrm{s}^{-1}$ for frequencies less than $10 \mathrm{~Hz}$ will not be exceeded at a reduced distance $\mathrm{LR}_{\mathrm{R}}=50$. In the upper left part of the graph are measured values of vibration velocities in the quarry $25 \mathrm{~m}$ from the initial borehole bench blast. In the lower right part are measured values peak particle velocities in residential buildings (Pandula and Kondela, 2021).

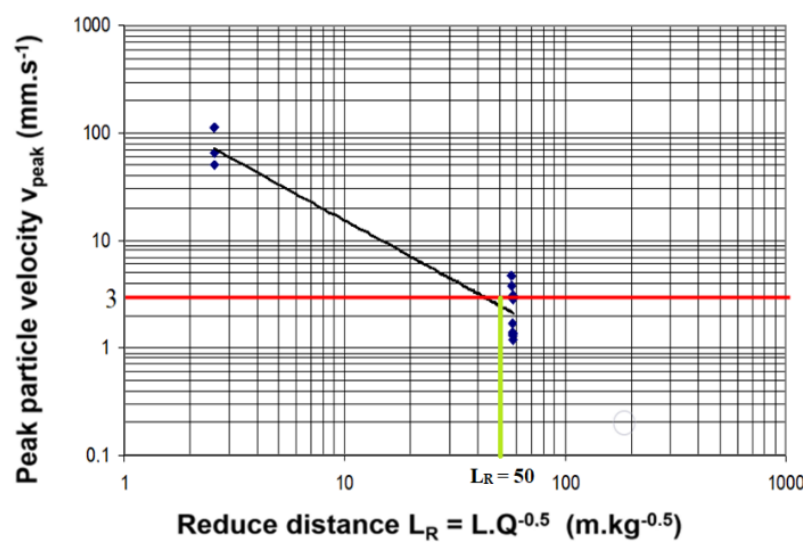

Figure 5. Graphic dependence of the maximum components of the peak particle velocity on the reduced distance during bench blasting in the quarry - the law of attenuation of seismic waves.
The red line indicates the maximum safe allowed peak particle velocities for buildings in the village (Pandula, Kondela, 2021).

Mining at the quarry site is carried out by bench blasting. Based on the measured and calculated values during the operational blasting in the quarry, the law of attenuation of seismic waves was determined, on the basis of which it is possible to use the maximum permissible charge weight per borehole depending on the distance during repeated bench blasting in quarry.

\begin{tabular}{|c|c|c|}
\hline $\begin{array}{c}\text { Distance } \\
\text { from } \\
\text { blasting } \\
(\mathbf{m})\end{array}$ & $\begin{array}{c}\text { Calculation for } \\
\mathbf{L}_{\mathbf{R}}=\mathbf{5 0}(\mathbf{m} \cdot \mathbf{k g}- \\
\mathbf{0 . 5})\end{array}$ & $\begin{array}{c}\text { Maximum charge } \\
\text { weight per borehole } \\
(\mathbf{k g})\end{array}$ \\
\hline 100 & $\begin{array}{c}\mathrm{Q}_{\mathrm{vmax}}=\mathrm{L}^{2} / \mathrm{LR}^{2}= \\
100^{2} / 50^{2}=\end{array}$ & 4 \\
\hline 200 & $\begin{array}{c}\mathrm{Q}_{\mathrm{vmax}}=\mathrm{L}^{2} / \mathrm{LR}^{2}= \\
200^{2} / 50^{2}=\end{array}$ & 16 \\
\hline 300 & $\begin{array}{c}\mathrm{Q}_{\mathrm{vmax}}=\mathrm{L}^{2} / \mathrm{L}^{2}= \\
300^{2} / 50^{2}=\end{array}$ & 36 \\
\hline 400 & $\begin{array}{c}\mathrm{Q}_{\mathrm{vmax}}=\mathrm{L}^{2} / \mathrm{L}^{2}= \\
400^{2} / 50^{2}=\end{array}$ & 64 \\
\hline 500 & $\begin{array}{c}\mathrm{Q}_{\mathrm{vmax}}=\mathrm{L}^{2} / \mathrm{LR}^{2}= \\
500^{2} / 50^{2}=\end{array}$ & 100 \\
\hline
\end{tabular}

Table 2. Calculation of the maximum permissible charge weight per borehole depending on the distance during repeated bench blasting in the quarry when applying the method.

From the point of view of seismic safety, these values are safe for buildings and residents, and in compliance with the proposed maximum permitted blasting charges for borehole, depending on the distance from residential buildings, there will be no damage to buildings (Pandula, Kondela, 2021).

\section{CONCLUSION}

Every mining operation that carries out blasting work is a source of vibration. Vibrations are perceived negatively if there are residential buildings or civil engineering structures in the vicinity of the operation. The negative effects of vibration cannot be completely eliminated, but they can be reduced. The presented methodology makes it possible to reduce the negative effects of vibration to a safe level. If we want to apply the presented methodology, it is necessary to experimentally determine the propagation velocity and dominant frequencies of seismic waves from blasting in individual mining operations, which are situated in different rock environments. Based on the experimentally determined parameters, it is possible to determine the optimal millisecond times delay of firing in individual boreholes. In research and practice, the law of attenuation of seismic waves, which best characterizes the transmission environment, has been verified. The law of seismic wave attenuation must be established for each position of the blasts towards the receptors. By law, it is possible to set the maximum charge per borehole depending on 
the distance of the receptor so that the effects of vibration are minimal. At the same time, it will make it possible to optimize the parameters of blasting operations in a mining operation so that there are no economic losses.

\section{REFERENCES}

Baulovič, J., Pandula, B., Kondela, J., Dugaček, D., 2016 Optimization of blasting in the quarry Trebejov. Exploration Geophysics, Remote Sensing and Environment, Vol. 23 (2), 1125.

Dojčár, O., Horky, J., Korinek, R., 1996: Blasting technology. Montanex, a.s., Ostrava, 421.

Dojčár, O., Pandula, B., 1998: Research of technical seismicity in the quarry Včeláre . Research report, F BERG TU Košice, 42.

Henrych, J., 1973: Explosion dynamics and its use. Académia, Praha. 273.

Langefors, U., Kihlström, B., 1978: The modern technique of Rock Blasting. A Halsted Press Book, 281-288.

Leššo, I., 1978: Optimization of millisecond timing delay of quarrying blastings. Manuscript, Košice, 15.

Makovička, D., Makovička, D., 2004: Failure of masonry under explosion effect, In: Jones, N., Brebbia, C.A.: Structures Under Shock and Impact VIII, WIT Press, Southampton, 475-484.

Mosinec, V. N., 1976: Decoupling and seismic events explosions in rocks. Nedra Moskva, 134

Pandula, B., Kondela, J., 2010: Methodology of seismic blasting works. Publisher: SSTVP DEKI Design, Ltd., Banská Bystrica,
Slovakia, 156.

Pandula, B., Kondela, J., Pachocka, K., 2012: Attenuation law of seismic waves in technical seismicity. Metalurgija, Vol. 51(3), 427-431.

Kondela, J., Pandula, B., 2012: Timing of quarry blasts and its impact on seismic effects. Acta Geodynamica et Geomaterialia, Vol. 9 (2), 155-163.

Pandula, B., Kondela, J., 2021: Measurement of the influence of technical seismicity in the quarry Lietavská Lúčka on the surrounding buildings. Research report, Košice, , TU FBERG, 28.

Sambuelli, L., 2009: Theoretical derivation of a peak particle velocity-distance law for the prediction of vibrations from blasting. Rock Mechanics and Rock Engineering, Vol. 42(3), 547556.

Soltys, A., Twardosz, M., Winzer, J., 2017: Control and documentation studies of the impact of blasting on buildings in the surroundings of open pit mines. Journal of Sustainable Mining, Vol. 16(4), 2017, 179-188.

Tatsuya, H., Gento, M. \& Kou, Sh., 2000: Optimum delay interval desing in delay blasting. International Journal for Blasting and Fragmentation. Vol. 4, No. 2, 139-148.

Viskup, J., Pandula, B., Leššo, I., Jelšovská, K., 2005: Spectra of seismic response. Acta Montanistica Slovaca, 10 (2005), 380386.

STN Eurokod 8, 2010: Design of structures for seismic resistance. Part 1, National Annex, Amendment 1 (STN EN 1998-1 / NA / Z1), Bratislava, Slovakia. 